DOI: $10.4274 /$ tftr.29319

\title{
Temporomandibuler Eklem Disfonksiyon Sendromlu Hastalarda Klinik ve Psikopatolojik Özellikler
}

\section{Psychopathological and Clinical Features in Patients With Temporomandibular Joint Dysfunction Syndrome}

\author{
Nazmiye KOCAMAN YILDIRIM, Mine ÖZKAN, Demirhan DIRAÇOĞLU*, Ilknur SARAL* , Ayşe KARAN*, Cihan AKSOY*, Sedat ÖZKAN \\ Istanbul Üniversitesi Istanbul Tıp Fakültesi, Psikiyatri Anabilim Dalı Konsültasyon Liyezon Psikiyatrisi Bilim Dalı, Istanbul, Türkiye \\ *Istanbul Üniversitesi Istanbul Tıp Fakültesi, Fiziksel Tıp ve Rehabilitasyon Anabilim Dalı, Istanbul, Türkiye
}

Özet

Amaç: Bu çalışmanın amacı, temporomandibuler eklem disfonksiyon sendromu (TMEDS) tanılı hastaları alt tanı gruplarına göre klinik ve psikopatolojik özellikler açısından karşılaştırmaktır.

Gereç ve Yöntem: Multidisipliner Temporomandibuler Eklem (TME) Tan ve Tedavi Ünitesi Polikliniği'ne başvuran ve TMEDS tanısı konan 200 hasta çalışmaya alındı. Hastalar yalnız miyofasiyal ağrısı olanlar (Grup-1), yalıız TME hastalığı olanlar (Grup-2) ve TME hastalığı ile birlikte miyofasiyal ağrısı olanlar (Grup-3) şeklinde üç alt gruba ayrıldı. Tüm hastalara standart TME muayenesi yapıldı. Hastalar psikopatolojik özellikler açısından Kısa Semptom Envanteri (KSE) ve Toronto Aleksitimi Ölçeği (TAÖ) ile değerlendirildi.

Bulgular: Grup-2'de diğer iki gruba göre maksimal ağız açıklığı, Grup-1'e göre ise sağ ve sol maksimal lateral hareket anlamlı olarak daha azdı. Grup-3'te Grup-1'e göre maksimal protrüzyon anlamlı biçimde daha az bulundu. Grup-2'de diş sıkma/gıcırdatmanın ve stresin etkisi Grup-3'e göre anlamlı olarak daha azdı. Grup-2'ye göre, Grup-1'deki hastaların KSE somatizasyon puanları, Grup-3'deki hastaların depresyon, anksiyete ve belirti toplam indeks puanları anlamlı biçimde daha yüksek bulundu. Üç grup arasında aleksitimi düzeyi açısından fark saptanmadı.

Sonuç: Yalnız miyofasial ağrıı olan ya da TME hastalığına eklenen miyofasiyal ağrısı olan hastaların psikopatolojik açıdan daha riskli olduğu görülmektedir. Klinisyenlerin bu hastalarda psikopatolojileri dikkate almaları gerekmektedir. Türk Fiz Tıp Rehab Derg 2012;58:9-15.

Anahtar Kelimeler: Temporomandibuler eklem disfonksiyon sendromu, miyofasiyal ağrı, anksiyete, somatizasyon, depresyon, aleksitimi

\section{Summary}

Objective: The aim of this study was to compare the clinical and psychopathological variables among temporomandibular joint dysfunction syndrome (TMDS) subgroups.

Metarials and Methods: In this study, we included two hundred individuals, who appealed to outpatient clinic of the Multidisciplinary Temporomandibular Joint (TMI) Diagnosis and Management Unit and were diagnosed with TMDS. The subjects were divided into three subgroups: only myofascial pain group (Group-1), only TMJ disorder group (Group-2) and myofascial pain+TM] disorder group (Group-3). All patients underwent standard TMJ examination. The patients were evaluated with the Brief Symptom Inventory (BSI) and the Toronto Alexithymia Scale (TAS) in terms of psychopathological features.

Results: Maximum mouth opening was found significantly lesser in Group-2 than in the other two groups, right and left lateral movements were found significantly lesser in Group-2 than in Group-1. Maximum protrusion was found significantly lesser in Group-3 than in Group-1. In Group-2, teeth clenching/grinding and the effect of stress were significantly less. In comparison with Group-2, BSI somatization scores in Group-1 patients, depression, anxiety, and symptoms total index scores in Group-3 patients were found to be significantly higher. No difference was found for the level of alexithymia between the groups.

Conclusion: The patients with myofascial pain alone or myofascial pain and intercurrent TMJ disorder were found more likely to have a greater psychopathological risk. Clinicians should take into consideration the psychopathologies in these patients. Turk J Phys Med Rehab 2012;58:9-15. Key Words: Temporomandibular joint dysfunction syndrome, myofascial pain, anxiety, somatization, depression, alexithymia 


\section{Giriş}

Temporomandibuler eklem disfonksiyon sendromu (TMEDS) temporomandibuler eklemin (TME), mastikatör kasların ya da her ikisinin birlikte etkilendiği, genellikle kronik ağrıla karakterize olan heterojen bir hastalık grubudur (1). Genel popülasyonun \%93'ünde TMEDS'nin bazı alt tiplerinin var olduğu ve \%5-13'ünde klinik olarak önemli semptomların bulunduğu bildirilmektedir (2). TMEDS her yaşta görülebilmesine rağmen, en sık 20-40 yaşları arasında görülmektedir ve cinsiyetin rolü tartışmalıdır $(3,4)$. Etiyolojisi açıkça anlaşılamasa da fiziksel, fonksiyonel, psikolojik, çevresel birçok faktörün katkısı olduğu düşünülmektedir $(1,4)$. TMEDS ile pek çok farklı branş ilgilenmekte, çoğu hasta hangi durumda hangi branş hekimine başvuracağını ya da pek çok hekim hastasını nasıl yönlendireceğini bilememektedir. Bu hastaların multidisipliner bir ekiple biyopsikososyal olarak değerlendirilmesi ve tedavi edilmesi gereklidir (5).

TMEDS'ye bir takım psikolojik sorunların eşlik ettiği bilinmektedir. TMEDS hastalarında sıklıkla anksiyete, depresyon (6-9) ve somatizasyon $(6,7,10,11)$ saptandığı, aleksitimi $(12)$ ve kişilik bozukluklarının (9) da araştırıldığı bildirilmektedir. Aleksitimi, duyguları tanıma, ayırt etme, tanımlama ve ifade etme güçlüğü olarak bilinen bir kişilik özelliğidir (13). Ülkemizde TMEDS hastalarını sağlıklı kontrollerle genetik ve psikometrik açıdan karşılaştıran (14) ve kişilik özelliklerini inceleyen az sayıda çalışma mevcuttur $(15,16)$. TMEDS'ne eşlik eden psikopatolojik durumların tanılanması son yıllarda bu alandaki çalışmaların temel hedefleri arasındadır $(17,18)$. Ancak, TMEDS alt gruplarında hastaların psikolojik durumundaki farklılıkları değerlendiren çalışmalar yetersiz sayıdadır ve bulunan sonuçlar çelişkilidir (17-21).

$\mathrm{Bu}$ çalışmanın amacı, TMEDS hastalarının farklı alt tanı gruplarında klinik ve psikopatolojik özellikler açısından fark olup olmadığını belirlemek ve eğer fark varsa hangi alt tanı grubunda psikopatojik hastalık açısından dikkatli olunması gerektiğini tesbit etmektir.

\section{Gereç ve Yöntem}

İstanbul Üniversitesi İstanbul Tıp Fakültesi, Fiziksel Tıp ve Rehabilitasyon Anabilim Dalı, Multidisipliner Temporomandibuler Eklem Tanı ve Tedavi Ünitesi'nde fiziksel tıp ve rehabilitasyon uzmanları, diş hekimleri, plastik cerrahi ve konsültasyon liyezon psikiyatrisi uzmanları hastaları bir ekip olarak değerlendirmektedir. Bu çalışmada multidisipliner polikliniğe TME bölgesi ağrısı ile başvuran ardışık 224 hasta değerlendirildi. Aşağıdaki kriterleri karşılayan 200 TMEDS tanılı hasta çalışmaya alındı. TME bölgesinde en az 6 aydır istirahat ya da eklem hareketi ile ortaya çıkan ağrısı olan ve TME hareketlerinde (tek ya da çift taraflı) zorlanma tarif eden hastalar TMEDS tanısı ile çalışmaya alındı. On sekiz yaşın altındakiler, okur-yazar olmayanlar, muayene ve sorgulama sırasında refakatçi yardımına gereksinim duyanlar, bilinen bir bilişsel işlev bozukluğu ya da önemli yeti yitimi yaratan nörolojik, psikiyatrik veya dekompanse sistemik hastalığı olanlar ve çalışmaya katılmak için onay vermeyen hastalar çalışmaya alınmadı.

Yarı yapılandırılmış görüşme formu doğrultusunda hastaların demografik bilgileri alındı. Şikayetleri, semptomların süresi, diş sıkma ya da diş gıcırdatma davranışının varlığı sorgulandı. Hastaların muayenesinde, TME hareket açıklıkları (maksimal ağız açıklığı, sağ ve sol maksimal lateral hareketler ve maksimal protüzyon değerleri) mezura ile ölçüldü. Hastalardan çene hareketleriyle ortaya çıkan TME ağrılarını $10 \mathrm{~cm}$ 'lik vizüel analog skala (VAS) ile değerlendirmeleri istendi. Hastaların masseter, temporal, lateral pterigoid ve digastrikus kaslarının herhangi birinde gergin band ve band içinde palpasyonla yayılan ağrıya neden olan tetik nokta/noktalar tesbit edilen hastalar miyofasiyal ağrı alt grubuna (Grup-1) (22), muayene ile eklemde hassasiyetin yanı sıra açılma-kapanma kliği ya da krepitasyon tespit edilenlerle eklem hareket açıklığında belirgin azalma olan hastalar TME hastalığı alt grubuna (Grup-2), her iki bulgu grubunu birlikte taşıyan hastalar ise TME + miyofasiyal ağrı grubuna (Grup-3) dâhil edildi. Hastaların TME muayeneleri çalışmanın yazarlarından en az iki hekim tarafından ortaklaşa olarak yapıldı. Ayrıca hastalardan şikâyetlerinin başlamasında fiziksel ve/veya psikososyal sebeplerin varlığı öğrenildi. Stresin etkisini belirlemek amacıyla hastalara şikâyetlerinin başladığı süreçte yaşamlarında önemli bir değişim, stres faktörü olup olmadığı ve stresle şikâyetlerinin değişip değişmediği de soruldu. Böylece stresin hastalığı başlatmada ve artırmada etkisi "var" "yok" olarak değerlendirildi. Hastaların daha önce psikiyatrik başvurusunun olup olmadığı bilgisi de alındı.

Kısa Semptom Envanteri (KSE), SCL 90-R'nin kısaltılmış formu olup, ergen ve yetişkinlerde çeşitli psikolojik belirtileri taramak amacı ile kullanılmaktadır (23). 53 maddeden oluşur ve kendi kendine uygulanabilen Likert tipi (hiç yok=0 ile çok fazla var=4 arasında değişen 5 kategoride) bir ölçektir. Ölçekten alınan toplam puanların yüksekliği bireyin belirtilerinin şiddetini göstermektedir. KSE, somatizasyon, obsesif-kompülsif bozukluk, kişilerarası duyarlılık, depresyon, anksiyete, hostilite, fobik anksiyete, paranoid düşünceler, psikotizm ve ek maddeler olmak üzere 10 alt ölçek ve rahatsızlık ciddiyeti indeksi (RCi), belirti toplamı indeksi (BTi) ve global semptom indeksi (GSi) olmak üzere 3 global indeksten oluşur. KSE'nin Türkçe geçerlilik ve güvenilirliği Şahin ve ark. (24) tarafından yapılmıştır.

Toronto Aleksitimi Ölçeği, Taylor ve ark. (25) tarafından geliştirilen, bireylerdeki aleksitimik özellikleri belirlemeyi amaçlayan, 26 maddeden oluşan, özgün formu Likert tipi olan bir öz bildirim ölçeğidir. Türkiye'de geçerlilik ve güvenilirlik çalışması 1990 ve 1991 yıllarında Dereboy $(26,27)$ tarafından yapılmıştır. Uyarlama çalışmasında ölçek evet/hayır şeklinde iki seçenekli hale getirilmiştir. Ölçekten alınan puanların yükselmesi aleksitiminin de artığı anlamına gelmektedir.

Araştırmanın planlama ve uygulama safhalarında Helsinki Deklerasyonu prensiplerine uygun olmasına dikkat edildi. Çalışmaya katılmada gönüllülük esası dikkate alındı ve her hastadan çalışmaya katılımı ile ilgili yazılı ve sözlü onay alındı. Verilerin istatistiksel olarak değerlendirilmesinde SPSS 15.0 paket programı kullanıldı. Hastaların demografik, fiziksel ve psikolojik 
özelliklerinin karşılaştırılmasında verilerin normal dağılıma uymaması nedeniyle parametrik olmayan Ki-kare ve Kruskal Wallis Testleri kullanıldı. Kruskal Wallis kullanılan değişkenlerde çoklu karşılaştırmalar z testi ile yapıldı.

\section{Bulgular}

TMEDS hastalarının yaş ortalaması 34,03 $\pm 12,11$ (18-65) yıl'dı ve \%85'i ( $n=171$ ) kadın idi. Çene eklem şikâyetlerinin ortalama süresi $26,71 \pm 30,65$ (1-144) ay ve hastaların \%44,5'inin başvuru şikâyeti hem ağrıyı, hem ses gelmesini ve hareket bozukluğunu içermekteydi. Hastaların \%44,5'i şikayetlerinin fiziksel sebeplerle (ağız içi girişim, travma, kaza vb.) başladığını ifade etti. Şikâyetlerin başlamasında ve artmasında stresin etkisi sorulduğunda hastaların $\% 71,5^{\prime} i$ stresin rolü olduğunu bildirdi. Hastaların \%66,3'ünde diş sıkma ya da diş gıcırdatma davranışının olduğu saptandı. \%83,1'inin daha önce psikiyatri başvurusunun olmadığı anlaşıldı.

TMEDS alt tanı dağılımına bakıldığında, hastaların \%40'ına yalnız miyofasiyal ağrı (Grup-1), \%21'ine yalnız TME hastalığı
(Grup-2), \%39'una hem miyofasiyal ağrı, hem TME hastalığı (Grup-3) tanısı konduğu saptandı. Gruplar arasında demografik özellikler (yaş, cinsiyet) açısından istatistiksel olarak anlamlı bir farklıık yoktu (Tablo 1). Fiziksel durum (şikâyetlerin süresi, ağrı şiddeti, maksimal ağız açıklığı, maksimal protrüzyon, sağ ve sol maksimal lateral hareket) ile ilgili tanılar arası karşılaştırma sonuçları Tablo 2'de verildi. Grup-2'de diğer iki gruba göre maksimal ağız açıklığı $(p=0,003)$, Grup-3'te Grup-1'e göre maksimal protrüzyon $(p=0,02)$, Grup-2'de Grup-1'e göre sağ $(p=0,01)$ ve sol $(p=0,03)$ maksimal lateral hareket ortalaması daha az olarak saptandı.

Hastaların tanı gruplarına göre diş sıkma/gıcırdatma, stresin etkisi, psikiyatrik özgeçmiş bulguları Tablo 3'de verildi. Grup-2'de Grup-3'e göre diş sıkma ya da diş gıcırdatmanın $(p=0,009)$, stresin etkisinin $(p=0,01)$ daha az oranda olduğu saptandı. Psikopatolojik belirtiler karşılaştırıldığında Grup-2'de KSE tüm alt ölçek puanlarının diğer iki gruba göre düşük olduğu görüldü. Grup-2'ye göre, Grup-1'deki hastaların somatizasyon $(p=0,01)$, Grup-3'deki hastaların depresyon $(p=0,04)$, anksiyete $(p=0,01)$ ve belirti toplam indeks $(p=0,01)$ puanının yüksek olduğu bulundu. Üç grup arasında aleksitimi puanı ortalamaları açısından anlamlı bir fark saptanmadı (Tablo 4).

Tablo 1. TMEDS'li hastaların üç alt tanı grubuna göre demografik özelliklerinin karşılaştırılması.

\begin{tabular}{|c|c|c|c|c|c|}
\hline Demografik Özellikler & Grup-1 $(n=80)$ & Grup-2 $(n=42)$ & Grup-3 $(n=78)$ & $K W \chi^{2}$ & $\mathrm{p}$ \\
\hline \multicolumn{6}{|l|}{ Yaş } \\
\hline Ortanca (min-max) & $34,5(18-65)$ & $32(18-65)$ & $31(18-60)$ & 1,314 & 0,518 \\
\hline \multicolumn{6}{|c|}{$\chi^{2}$} \\
\hline $\begin{array}{l}\text { Cinsiyet } \\
\text { (Kadın:Erkek) }\end{array}$ & $63: 17$ & $38: 4$ & $70: 8$ & 4,912 & 0,09 \\
\hline
\end{tabular}

(Grup-1) yalnız miyofasiyal ağrısı olanlar

(Grup-2) yalnız TME hastalığı olanlar

(Grup-3) TME hastalığı ile birlikte miyofasiyal ağrısı olanlar

Tablo 2. TMEDS'li hastaların üç alt tanı grubuna göre klinik özelliklerinin karşılaştırılması.

\begin{tabular}{|c|c|c|c|c|c|c|}
\hline Klinik Özellikler & $\begin{array}{l}\text { Grup-1 ( } n=80) \\
\text { ortanca (min-max) }\end{array}$ & $\begin{array}{l}\text { Grup-2 ( } n=42) \\
\text { ortanca (min-max) }\end{array}$ & $\begin{array}{l}\text { Grup-3 ( } n=78) \\
\text { ortanca (min-max) }\end{array}$ & $\mathrm{KW} \chi^{2}$ & $\mathrm{p}$ & $\begin{array}{l}\text { Anlamlı fark } \\
\text { (KW z test) }\end{array}$ \\
\hline Şikâyetlerin süresi (ay) & $12(1-14)$ & $24(1-120)$ & $18(1-120)$ & 4,396 & 0,111 & - \\
\hline Ağrı şiddeti (VAS-cm) & $6(0-10)$ & $5(0-9)$ & $5(0-10)$ & 3,614 & 0,164 & - \\
\hline Maksimum ağız açıklığı (mm) & $40(23-60)$ & $35(10-2)$ & $40(0-65)$ & 11,824 & 0,003 & $2-1,2-3$ \\
\hline Maksimum protrüzyon (mm) & $5(0-20)$ & $4(1-10)$ & $3(0-18)$ & 7,541 & 0,02 & $3-1$ \\
\hline Maksimum sağ lateral hareket (mm) & $9(1-20)$ & $6(0-17)$ & $8(1-20)$ & 8,748 & 0,01 & $2-1$ \\
\hline Maksimum sol lateral hareket (mm) & $8,5(0-20)$ & $7(0-23)$ & $8(1-20)$ & 6,760 & 0,03 & $2-1$ \\
\hline
\end{tabular}

(Grup-1) yalnız miyofasiyal ağrısı olanlar

(Grup-2) yalnız TME hastalı̆ı olanlar

(Grup-3) TME hastalığı ile birlikte miyofasiyal ağrısı olanlar 


\section{Tartışma}

Bu çalışmada, TMEDS'li hastalar arasında saf miyofasiyal ağrısı olan ya da eklem hastalığına eklenen miyofasiyal ağrısı olan hastaların saf eklem hastalarına göre somatizasyon, anksiyete, depresyon, belirti toplam indeks puanı gibi psikopatolojik parametrelerde daha yüksek değerlere sahip oldukları tespit edilmiştir.

TMEDS her yaşta görülebilmesine rağmen, en sık genç yetişkinlik döneminde görülmektedir (4). Çalışmamızda yaş ortalaması bu genel bilgilerle uyumlu olup, kadın oranı erkeklerden yaklaşık 6 kat daha fazla bulunmuştur. Romanelli ve ark. (28) da kadın-erkek dağılımı açısından bizimle benzer sonuçlar saptamıştır. Ozan ve ark. (29) ülkemizde yaptıkları prevalans çalışmasında TMEDS'nin kadınlarda daha fazla görüldüğünü bulmuştur. Kadın oranının yüksekliği, hormonal, psikolojik ve ergonomik nedenlerle açıklanmaya çalışıldığı gibi, kadınların daha fazla tedavi arayışında olmasına da bağlı olabilir (30). Çalışmamızda hastaların yaş ortalaması ve kadın erkek oranı üç farklı alt tanı grubuna göre bakıldığında farklılık göstermemektedir. Bu sonuç diğer çalışmalarla da uyumludur $(17,18,20,31)$.

Çalışmamızda, yalnız eklem hastalığı olan grupta şikâyetlerin süresinin daha uzun olduğu ancak bu farkın anlamlı olmadığı saptanmıştır. Bir çalışmada, miyofasiyal ağrının kronik TMEDS gelişimine katkı sağladığı belirtilse de bu konuda net bir bilgi yoktur (32). Çalışmamızda, yalnız eklem hastalığı bulunan grupta temporomandibuler fonksiyonların diğer gruplara göre daha fazla bozulduğu görülmektedir. Buna göre oro-mandibuler fonksiyonunun kas ağrısından çok eklem ağrısından etkilendiği söylenebilir. Bu sonucu destekleyen çalışmalar olduğu gibi (18), eklem ya da kas rahatsızlığı olan gruplar arasında fonksiyonel problemler açısından fark bulunamayan çalışmalar da vardır $(33,34)$. Çalışmamızda ağrı

Tablo 3. TMEDS'li hastaların üç alt tanı grubuna göre diş sıkma ya da gıcırdatma varlığı, stresin etkisi ve psikiyatrik özgeçmişlerinin karşılaşıııılması.

\begin{tabular}{|c|c|c|c|c|c|c|c|}
\hline & \multicolumn{2}{|c|}{$\begin{array}{l}\text { Grup-1 } \\
\text { (n) } \%\end{array}$} & \multicolumn{2}{|c|}{$\begin{array}{l}\text { Grup-2 } \\
\text { (n) } \%\end{array}$} & \multicolumn{2}{|c|}{$\begin{array}{l}\text { Grup-3 } \\
\text { (n) } \%\end{array}$} & $\mathrm{p}$ \\
\hline \multicolumn{7}{|c|}{ Diş sıkma ya da gıcırdatma varlığı } & 0,009 \\
\hline Yok & 18 & 22,5 & 21 & 51,2 & 28 & 35,9 & \\
\hline $\begin{array}{l}\text { Diş sıkma ya da } \\
\text { diş gıcırdatma }\end{array}$ & 38 & 47,5 & 10 & 24,4 & 33 & 42,3 & \\
\hline Her ikisi de & 24 & 30,0 & 10 & 24,4 & 17 & 21,8 & \\
\hline \multicolumn{7}{|c|}{ Stresin hastalı̆̆ başlatmada/artırmada etkisi } & 0,01 \\
\hline Evet & 58 & 72,5 & 23 & 54,8 & 62 & 79,5 & \\
\hline Hayır & 22 & 27,5 & 19 & 45,2 & 16 & 20,5 & \\
\hline \multicolumn{7}{|c|}{ Psikiyatrik özgeçmiş } & 0,660 \\
\hline Evet & 14 & 17,9 & 5 & 12,2 & 14 & 18,4 & \\
\hline Hayır & 64 & 82,1 & 36 & 87,8 & 62 & 81,6 & \\
\hline
\end{tabular}

BSCÖ: Boston Semptom Ciddiyet Ölçeği

r: Korelasyon katsayısı

$\mathrm{p}$ : korelasyon $\mathrm{p}$ değeri şiddeti açısından gruplar arası anlamlı farklılık saptanmadı. Reissmann ve ark. (18) yaptıkları çalışmada, bizim bulgularımıza benzer şekilde üç grup arasında VAS ağrı şiddeti açısından fark saptanmadığını bildirmişlerdir. Yine başka bir çalışmada, mastikatör kas ağrısı ve intrakapsüler eklem ağrısı arasında ağrı şiddeti ve süresi açısından fark olmadığı saptanmıştır (35).

Çalışmamızda, yalnız TME hastalarına göre (Grup-2), yalnız miyofasiyal ağrılı (Grup-1) ya da eklem hastalığıyla birlikte miyofasiyal ağrılı gruptaki (Grup-3) hastaların şikâyetlerinin başlamasında ya da artmasında stresin etkisi olduğu, diş sıkma veya gıcırdatmanın yüksek olduğu saptanmıştır. TME bölgesinde miyofasiyal ağrının oluşumunda diş gıcırdatmanın potansiyel risk faktörlerinden biri olduğu bilinmektedir (36). Ayrıca diş sıkma veya gıcırdatmanın gün içi yaşanan emosyonel zorlanmaların etkisiyle arttığı ya da ortaya çıktığı ileri sürülmektedir (37). Stres kökenli merkezi nedenlerin başlattığı, genellikle çene kaslarını kasma ve diş gıcırdatma gibi parafonksiyonel alışkanlıklarla birlikte olan kas geriliminin, kasta ağrı ve güçsüzlükle sonuçlanan spazm ve kas zaafiyetine neden olduğu ileri sürülmektedir. Bu sonuç yüksek düzeyde emosyonalitenin, mandibular kasların hiperaktivitesine neden olduğu teorisi üzerine temellendirilmiştir (38-40). Çalışmalar, TMEDS hastalarının kaslarında hiperaktivitenin ortaya çıktığını, bunun stresle başlayabildiğini (41-43) ve bu hastaların eşleştirilmiş kontrol grubuna göre daha fazla stresli yaşam olaylarına maruz kaldığını göstermektedir $(44,45)$.

Miyofasiyal ağrılı hastalarda psikiyatrik öykü ve psikotrop ilaç kullanımının daha yüksek olduğu saptanmıştır (6). Çalışmamızda, psikiyatrik hastalık öyküsü açısından gruplar arasında fark saptamadık. Bu sonuç ülkemizde hastaların psikiyatriye başvurma oranlarının düşük olmasına bağlı olabilir. Hastalar psikiyatrik değerlendirmede, daha önce psikolojik desteğe ihtiyaç hissettiklerini ama profesyonel yardım almadıklarını sıklıkla ifade etmişlerdir. Çeşitli çalışmalardan elde edilen veriler TMEDS'nin anksiyete, depresyon ve somatizasyon gibi psikososyal bozukluklarla ilişkili olduğunu desteklemektedir (7,46-50).

TMEDS alt tanı gruplarına göre yapılan çalışmalarda, psikopatolojilerin eklem rahatsızlığından çok miyofasiyal ağrıya eşlik ettiği gösterilmiştir $(38,51)$. Ancak TMEDS ve psikopatoloji arasındaki kompleks ilişki son yıllarda kronik ağrıya bağlanmakta, bu konudaki veriler de giderek artmaktadır $(18,52,53)$. Bizim çalışmamızda, yalnız TME rahatsızlıklarında (Grup-2) KSE ölçeği ile gösterilen somatizasyon, depresyon ve anksiyete düzeyinin diğer iki gruba göre anlamlı olarak daha düşük olduğu bulunmuştur. Çalışmamızda, kısa formunu kullandığımız SCL-90-R ile Manfredini ve ark.'nın (17) yaptıkları çalışmada, yalnız miyofasiyal ağrı ya da TME hastalığına eklenen miyofasiyal ağrısı olan kişilerin tüm alt ölçek puanları, yalnız TME hastalığı olan kişilerden daha yüksek bulunmuştur. Belirti toplam indeks puanı da TME hastalarında istatistiksel olarak anlamlı düzeyde düşük saptanmıştır. Bu bulgular bizim bulgularımızla büyük oranda örtüşmektedir. Bizim çalışmamamızdan farklı olarak depresyon, anksiyete ve somatizasyon puanlarının gruplar arasında istatistiksel olarak anlamlı fark yaratmadığını saptamışlar ancak bu sonucu açıklayamamışlardır. Burada çalışmamızdaki hasta sayısının Manfredini ve ark.'nın (17) 
hasta sayısından çok daha fazla olduğuna dikkat çekmek istiyoruz. Aynı yazarların bizim bulgularımızı destekleyen başka bir çalışmasında, miyofasiyal ağrılı hastaların hem duygudurum, hem panik-agorafobik prevalansı anlamlı olarak daha yüksek bulunmuştur (20).

TMEDS'nin yedi gruba ayrılarak değerlendirildiği bir başka çalışmada, somatizasyon ve depresyon puanları miyofasiyal ağrı ve osteoartrtitle birlikte giden TME hastalarında en yüksek saptanmıştır (10). Galdon ve ark. (21) kas ve eklem rahatsızlığı olan hastaları karşılaştırdığı çalışmasında, kas rahatsızlığı olan hastaların anksiyete ve somatizasyon puanlarının yüksek olduğu saptanmıştır. Ayrıca bu hastaların parafonksiyonel alışkanlıkları olduğu belirtilmiştir. Başka bir çalışmada da miyojenik ağrı hastalarında anksiyete prevalansı TME hastalığı ve nöropatik ağrı grubuna göre daha yüksek bulunmuştur (47). Emosyonel problemlerin en fazla miyofasiyal ağrı hastalarında, en az disk patolojileri olan hastalarda ortaya çıktığı bildirilmiştir $(33,54)$. Görüldüğü gibi bu sonuçlar çalışmamızla paralellik göstermektedir. Ancak bir grup araştırmacının sonuçları tamamen farklıdır $(6,18)$. Ortaya çıkan bu farklıık hasta seçim kriterlerinin tam olarak standardize edilememesine bağlı olabilir. Çalışmamızda TMEDS'nin ana alt gruplarındaki psikopatolojik sonuçların değerlendirilmesi amaçlandığından hastaları üç alt gruba ayırarak sonuçları değerlendirdik. Ancak bu yaklaşım aynı alt grupta rölatif heterojeniteye neden olmuş olabilir. Bu da araştırmamızın bir limitasyonu olarak değerlendirilebilir. Çalışmamızın bir diğer muhtemel limitasyonu miyofasiyal tetik nokta tanısının manuel palpasyonla konmuş olmasıdır. Çünkü manuel yöntemin tekrarlanabilirliği konusu tartışmalıdır (55).

TMEDS hastalarında aleksitimi düzeyi nadiren çalışılmış bir konudur. Aleksitiminin genel popülasyonda görülme sıklığı \%23'ler düzeyindedir (56). Ülkemizde genç erişkin sağlıklı popülasyonda yapılan bir çalışmada TAÖ’den yüksek puan alanların oranı \%16,7 olarak bulunmuştur (57). Glaros ve ark. (15), ağrısı olan ve olmayan TMEDS hastaları ve sağlıklı kontrollerin toplam aleksitimi puanları arasında fark saptamamıştır. TMEDS ile aleksitimi arasında ilişkiyi araştıran bir çalışmada, aleksitiminin asemptomatik olgulardan ziyade orofasiyal semptomları olan olgularda yüksek olduğu bulunmuştur (50). Çalışmamızda aleksitimi düzeyinde gruplar arası anlamlı fark saptanmamıştır.

Sonuç olarak; çalışmamızda saf TME patolojisi olan hastalarda ağız açıklığı, sağ ve sol lateral hareket ortalamasının, diş sıkma/gıcırdatmanın, stresin etkisinin daha az olduğu ve miyofasiyal ağrı komponenti olan TMEDS hastalarının psikopatolojik açıdan daha yüksek risk taşıdığı görülmektedir. Bu sorunla ilgilenen hekimlerin TMEDS ile gelen hastalarda miyofasiyal ağrı komponentini iyi değerlendirmeleri ve eğer miyofasiyal ağrı komponenti mevcutsa psikopatolojik riskin artığını bilmeleri, tedavi programı düzenlenirken bu durumu göz önüne almaları önemlidir.

Tablo 4. TMEDS'li hastaların üç alt tanı grubuna göre psikiyatrik parametrelerin karşılaştırılması.

\begin{tabular}{|c|c|c|c|c|c|c|}
\hline $\begin{array}{l}\text { Klinik Özellikler } \\
\text { Kısa Semptom Envanteri (KSE) } \\
\text { Alt Ölçekler }\end{array}$ & $\begin{array}{l}\text { Grup-1 }(n=80) \\
\text { ortanca (min-max) }\end{array}$ & $\begin{array}{l}\text { Grup-2 }(n=42) \\
\text { ortanca (min-max) }\end{array}$ & $\begin{array}{l}\text { Grup-3 ( } n=78) \\
\text { ortanca (min-max) }\end{array}$ & $\mathrm{KW} \chi^{2}$ & $\mathrm{p}$ & $\begin{array}{r}\text { Anlamlı fark } \\
\text { (KW z test) }\end{array}$ \\
\hline Somatizasyon & $1,14(0,14-3,43)$ & $0,5(0,0-3,29)$ & $1,07(0,0-3,29)$ & 9,187 & 0,010 & $2-1$ \\
\hline Obsesif-kompülsif bozukluk & $1,33(0,0-3,67)$ & $1(0,0-3,50)$ & $1,25(0,17-3,67)$ & 4,101 & 0,129 & - \\
\hline Kişilerarası duyarlılık & $1(0,0-4,0)$ & $0,75(0,0-3,75)$ & $1,25(0,0-4,0)$ & 3,554 & 0,169 & - \\
\hline Depresyon & $0,83(0,0-4,17)$ & $0,58(0,0-3,50)$ & $1,16(0,0-3,67)$ & 6,210 & 0,045 & $2-3$ \\
\hline Anksiyete & $1,16(0,0-3,17)$ & $0,83(0,0-3,33)$ & $1,33(0,0-4,0)$ & 8,848 & 0,012 & $2-3$ \\
\hline Hostilite & $1,10(0,0-3,80)$ & $0,90(0,0-2,60)$ & $1,0(0,0-4,0)$ & 2,805 & 0,246 & - \\
\hline Fobik anksiyete & $0,80(0,0-3,40)$ & $0,40(0,0-3,20)$ & $0,60(0,0-3,40)$ & 4,732 & 0,094 & - \\
\hline Paranoid düşünceler & $1,20(0,0-4,0)$ & $0,80(0,0-11,80)$ & $1,20(0,0-4,0)$ & 2,793 & 0,248 & - \\
\hline Psikotizm & $0,60(0,0-3,0)$ & $0,60(0,0-3,0)$ & $0,60(0,0-3,60)$ & 0,531 & 0,767 & - \\
\hline Ek maddeler & $1,0(0,0-3,75)$ & $0,75(0,0-3,50)$ & $1,0(0,0-3,75)$ & 4,363 & 0,113 & - \\
\hline Rahatsızlık Ciddiyeti Indeksi & $1,0(0,11-3,11)$ & $0,74(0,11-2,83)$ & $1,02(0,23-3,32)$ & 5,449 & 0,066 & - \\
\hline Semptom Rahatsızlık İndeksi & $1,94(1,08-3,74)$ & $1,89(1,0-5,65)$ & $1,83(1,0-3,67)$ & 2,571 & 0,277 & - \\
\hline Belirti Toplamı İndeksi & $29(5,0-53,0)$ & $24(5,0-46,0)$ & $31(10-50)$ & 9,178 & 0,010 & $2-3$ \\
\hline KSE Toplam & $53,5(6,0-165)$ & $39,5(6,0-150)$ & $54,5(12-176)$ & 5,449 & 0,066 & - \\
\hline Aleksitimi & $10(2,0-35,0)$ & $10(2,0-19,0)$ & $10(2-21)$ & 0,538 & 0,764 & - \\
\hline
\end{tabular}

(Grup-1) yalnız miyofasiyal ağrısı olanlar

(Grup-2) yalnız TME hastalığı olanlar

(Grup-3) TME hastalığı ile birlikte miyofasiyal ağrısı olanlar 


\section{Teşekkür}

İstanbul Üniversitesi, İstanbul Tıp Fakültesi, Halk Sağlığı Anabilim Dalı, İş Sağlığı Bilim Dalı́ndan Doç. Dr. Halim İşsever'e makalenin istatistiksel analizindeki yardımlarından dolayı teşekkür ederiz.

\section{Çıkar Çatışması:}

Yazarlar herhangi bir çıkar çatışması bildirmemişlerdir.

\section{Kaynaklar}

1. Goldstein BH. Temporomandibular disorders. A review of current understanding. Oral Surg Oral Med Oral Pathol Oral Radiol Endod 1999;88:379-85

2. Carlsson CR. Epidemiology and treatment need for temporomandibular disorders. J Orofac Pain 1999;13:232-7.

3. Marbach JJ. Temporomandibular pain and dysfunction syndrome. History, phsical examination and treatment. Rheum Dis Clin North Am 1996;22:477-98.

4. Dworkin SF, Huggins KH, LeResche L, Von Korff M, Howard J, Truelove $\mathrm{E}$, et al. Epidemiology of signs and symptoms in temporomandibular disorders: clinical signs in cases and controls. I Am Dent Assoc 1990;120:273-81.

5. Suvinen TI, Reade PC, Kemppainen P, Könönen M, Dworkin SF. Review of aetiological concepts of temporomandibular pain disorders: towards a biopsychosocial model for integration of physical disorder factors with psychological and psychosocial illness impact factors. Eur I Pain 2005:9:613-33.

6. Nifosì F, Violato E, Pavan C, Sifari L, Novello G, Guarda Nardini L, et al. Psychopathology and clinical features in an Italian sample of patients with myofascial and temporomandibular joint pain: Preliminary data. Int J Psychiatry Med 2007;37:283-300.

7. Sirirungrojying S, Srisintorn S, Akkayanont P. Psychometric profiles of temporomandibular disorder patients in southern Thailand. J Oral Rehabil 1998;25:541-4.

8. Suvinen TI, Reade PC. Temporomandibular disorders: a critical review of the nature of pain and its assessment. J Orofac Pain 1995;9:317-39.

9. Gatchel RJ, Garofalo JP, Ellis E, Holt H. Major psychological disorders in acute and chronic TMD: an initial examination. J Am Dent Ass 1996;127:1365-74.

10. Yap AUJ, Tan KBC, Chua EK, Tan HH. Depression and somatization in patients with temporomandibular disorders. J Prosthet Dent 2002;88:479-84.

11. Yap AU, Chua EK, Tan KB, Chan YH. Relationships between depression/somatization and self-reports of pain and disability. J Orofac Pain 2004;18:220-5.

12. Glaros AG, Lumley MA. Alexithymia and pain in temporomandibular disorder. J Psychosom Res 2005;59:85-8.

13. Taylor GJ. Recent developments in alexithymia theory and research. Can J Psychiatry 2001;45:134-42.

14. Öz G, Öztürk A, Mutlu N, Herken H, Erdal ME. Temporomandibular disfonksiyonlu hastaların genetik ve psikometrik açıdan değerlendirilmesi. T Klin Diş Hek Bil 2002;8:120-5.

15. Darcan A, Onur E, Köse, Aklın T, Erdem A. Temporomandibuler bozukluğu olan hastalarda mizaç ve karakter boyutları. Türk Psikiyatri Dergisi 2008; 19:274-82.

16. Durutürk N, Daşkapan A, Tüzün EH, Aydan A. Fibromiyalji ve miyofasyal ağrı sendromlarında kişilik özellikleri. Fizyoterapi Rehabilitasyon 2008;19:129-35.

17. Manfredini D, Marini M, Pavan C, Pavan L, Guarda-Nardini L. Psychoscial profiles of painful TMD patients. J Oral Rehabil 2009;36:193-8.

18. Reissmann DR, John MT, Wassell RW, Hinz A. Psychosocial profiles of diagnostic subgroups of temporomandibular disorder patients. Eur J Oral Sci 2008;116:237-44.

19. Bertoli E, De Leeuw R, Schmidt JE, Okeson JP, Carlson CR. Prevalence and impact of post-traumatic stress disorder symptoms in patients with masticatory muscle or temporomandibular joint pain: differences and similarities. J Orofac Pain 2007;21:107-19.
20. Manfredini D, Bandettini di Poggio A, Cantini E, Dell'Osso L, Bosco M. Mood and anxiety psychopathology and temporomandibular disorders: a spectrum approach. J Oral Rehabil 2004;31:933-40.

21. Galdon MJ, Durá E, Andreu Y, Ferrando $M$, Poveda R, Bagán JV. Multidimensional approach to the differences between muscular and articular temporomandibular patients: coping, distress, and pain characteristics. Oral Surg Oral Med Oral Pathol Oral Radiol Endod 2006;102:40-6.

22. Simons DG, Travell JG, Simons LS. Travell and Simons' myofascial pain and dysfunction: the trigger point manual. Volume 1, 2nd ed. Baltimore: Williams \& Wilkins; 1999.

23. Derogatis LR, Melisaratos N. The Brief Symptom Inventory: an introductory report. Psychol Med 1983;13:595-605.

24. Sahin NH, Durak A. Brief Symptom Inventory-BSI: Version for Turkish Adolescents. Turkish Journal of Psychology 1994;31:44-56.

25. Taylor GJ, Bagby RM, Ryan DP, Parker JDA, Doody KF, Keefe P. Criterion Validity of the Toronto Alexithymia Scale. Psychosom Med 1988;50:500-9.

26. Dereboy F. Aleksitimi özbildirim ölçeklerinin psikometrik özellikleri üzerine bir çalışma, yayınlanmamış uzmanlık tezi, Hacettepe Üniversitesi Tıp Fakültesi, Ankara. 1990.

27. Dereboy IF. Aleksitimi: Bir gözden geçirme. Türk Psikiyatri Dergisi 1991;1:157-66.

28. Romanelli GG, Harper R, Mock D, Pharoah MJ, Tenenbaum HC. Evaluation of temporomandibular joint internal derangement. I Orofacial Pain 1993;7:254-62.

29. Ozan F, Polat S, Kara I, Küçük D, Polat HB. Prevalence study of signs and symptoms of temporomandibular disorders in a Turkish population. J Contemp Dent Pract 2007;8:35-42.

30. Warren MP, Fried JL. Temporomandibular disorders and hormones in women. Cells Tissues Organs 2001;169:187-92.

31. Bonjardim LR, Lopes-Filho RJ, Amado G, Albuquerque RL, Goncalves SR. Association between symptoms of temporomandibular disorders and gender, morphological occlusion, and psychological factors in a group of university students. Indian I Dent Res 2009;20:190-4.

32. Epker J, Gatchel RJ, Ellis E 3rd. A model for predicting chronic TMD: practical application in clinical settings. I Am Dent Assoc 1999;130:1470-5.

33. Kino $K$, Sugisaki $M$, Haketa $T$, Amemori $Y$, Ishikawa $T$, Shibuya $T$, et al The comparison between pains, difficulties in function, and associating factors of patients in subtypes of temporomandibular disorders. J Oral Rehabil 2005;32:315-25.

34. Reissmann DR, John MT, Schierz O, Wassell RW. Functional and psychosocial impact related to specific temporomandibular disorder diagnoses. J Dent 2007;35:643-50.

35. Lindroth JE, Schmidt JE, Carlson CR. A comparison between masticatory muscle pain patients and intracapsular pain patients on behavioral and psychosocial domains. J Orofac Pain 2002;16:277-83.

36. Huang G], LeResche L, Critchlow CW, Martin MD, Drangsholt MT. Risk factors for diagnostic subgroups of painful temporomandibular disrders (TMD). J Dent Res 2002;81:284-8.

37. Carlsson EG, Egermak I, Magnusson T. Predictors of bruxism, other oral parafunctions, and tooth wear over a 20-year follow-up period. J Orac Pain 2003;17:50-7.

38. Kight M, Gatchel RJ, Wesley L. Temporomandibular disorders: evidence for significant overlap with psychopathology. Health Psychol 1999;18:177-82.

39. Okeson JP. Management of temporomandibular disorders and occlusion. St Louis: Mosby Year Book; 1993.

40. Haley WE, Turner JA, Romano JM. Depression in chronic pain patients: Relation to pain, activity, and sex differences. Pain 1985;23:337-43.

41. Greene CS, Olson RE, Laskin DM. Psychological factors in the etiology, progression, and treatment of MPD syndrome. J Am Dent Assoc 1982; 105:443-8.

42. Moss RA, Garrett I, Chiodo JF. Temporomandibular joint dysfunction and myofascial pain dysfunction syndromes: Parameters, etiology, and treatment. Psychol Bull 1982;92:331-46.

43. Keefe FJ, Dolan EA. Correlation of pain behavior and muscle activity in patients with myofascial pain-dysfunction syndrome. I Craniomandib Disord 1988:2:181-4.

44. Speculand B, Hughes AO, Goss AN. Role of recent stressful life events experience in the onset of TMJ dysfunction pain. Community Dent Oral Epidemiol 1984;12:197-202. 
45. Stein S, Hart DL, Loft G, Davis H. Symptoms of TMJ dysfunction as related to stress measured by the social readjustment rating scale. J Prosthet Dent 1982;47:545-8.

46. Rollman GB, Gillespie JM. The role of psychosocial factors in temporomandibular disorders. Curr Rev Pain 2000;4:71-81.

47. Mongini F, Ciccone G, Ibertis F, Negro C. Personality characteristics and accompanying symptoms in temporomandibular joint dysfunction, headache, and facial pain. J Orofac Pain 2000;14:52-8.

48. Manfredini D, Landi N, Bandettini di Poggio A, Dell'Osso L, Bosco M. A critical review on the importance of psychological factors in temporomandibular disorders. Minerva Stomatol 2003;52:321-30.

49. Gallagher RM, Marbach JJ, Raphael KG, Dohrenwend BP, Cloitre M. Is major depression comorbid with temporomandibular pain and dysfunction syndrome? A pilot study. Clin J Pain 1991;7:219-25.

50. Sipilä K, Veijola J, Jokelainen J, Järvelin MR, Oikarinen KS, Raustia AM, et al. Association of symptoms of TMD and orofacial pain with alexithymia: an epidemiological study of the Northern Finland 1966 Birth Cohort. Cranio 2001;19:246-51.
51. Lundeen TF, Sturdevant JR, George JM. Stress as a factor in muscle and temporomandibular joint pain. J Oral Rehabil 1987;14:447-56.

52. Yap AU, Dworkin SF, Chua EK, List T, Tan KB, Tan HH. Prevalence of temporomandibular disorders subtypes, psychologic distress and psychosocial dysfunction in asian patients. J Orofac Pain 2003;17:21-8.

53. Manfredini D, Bandettini di Poggio A, Romagnoli M, Dell'Osso L, Bosco M. Mood spectrum in patients with different painful temporomandibular disorders. Cranio 2004;22:234-40.

54. Glaros AG. Emotional factors in temporomandibular joint disorders. Indiana Dent Assoc 2000-2001;79:20-3.

55. Myburgh C, Larsen AH, Hartvigsen J. A systematic, critical review of manual palpation for identifying myofascial trigger points: evidence and clinical significance. Arch Phys Med Rehabil 2008;89:1169-76.

56. Loas G, Fremaux D, Otmani O, Verrier A. Prevalence of alexithymia in a general Population. Ann Med Psychol 1995;153:355-7.

57. Candansayar S. Genç erişkin sağıkıı gönüllülerde aleksitimi prevalansı. XXIX. Ulusal Psikiyatri Kongresi. Özet Kitabı, Bursa, 29 Eylül-4 Ekim 1993:120. 